\title{
Criminal Law Policy against Actor of Criminal Performance Persecution
}

\author{
Muhammad Adiel Aristo ${ }^{1}$
}

Abstract: In simple terms, it can be described that the act of persecution starts with the act of identifying, searching for and executing the perpetrators who are suspected of committing criminal acts based on the above reasons, or in other words, that persecution is an act of judgment without going through the proper process or procedure, which in criminal law called the act of vigilante (eigenrechting). The formulation of the problem presented is how is the criminal law policy towards the perpetrators of criminal acts of persecution. The method of approach in research uses normative juridical research specifications in the form of analytical descriptive. Data consists of secondary data obtained from literature or document studies. Based on the research, it can be concluded that for certain conditions, in the act of vigilantism, especially in the case of selfdefense / property / honor, justification reasons can be used, because it meets the elements mentioned in the Criminal Code provisions, especially Article 49 of the Criminal Code. Unlike the case with the act of persecution, in the act of persecution there are no elements that can be used as justification and excuse for forgiveness in their actions, because when viewed from the process, the act of persecution, begins with finding,

Keywords: Criminal Law Policy; Perpetrators; Criminal Acts of Execution.

\section{Introduction}

In accordance with the explanation in Article 1 paragraph (3) of the 1945 Constitution of the Republic of Indonesia (1945 Constitution), it is clearly stated that "Indonesia is a Rule of Law". If the provisions are interpreted grammatically, then there will be consequences from a rule of law, namely that all forms of decisions, actions of state equipment, all attitudes, behavior and actions including those committed by citizens, must have a legal basis or in other words, all must have legal legitimacy.

However, the reality of criminal law in society is not as easy as stated above, many complex and emerging problems, including the problem of criminal acts which are increasingly developing and varying, along with the development of society towards the modern era. Growing and increasing crime problems, indirectly raises an assumption from the public, that law enforcement officers fail to overcome the problem and are considered slow in carrying out their duties and there is public dissatisfaction in law enforcement. This is due to the lengthy process of the judicial system which is less educative, wherein a frequent occurrence of suspected

\footnotetext{
${ }^{1}$ Student of Master of Law, Universitas Islam Sultan Agung Semarang and Indonesian Police, email: Aristo2008pr@gmail.com
} 
perpetrators of crimes and harming the community, released by law enforcement on the grounds of lack of evidence, even if the case is processed until the court,

In fact in the science of law, persecution has long been known, namely by the term vigilante or eigenrechting. In the legal dictionary, it is stated that Eigenrechting is an act to exercise rights according to one's own will is nothing but an act to exercise rights according to one's own will that is arbitrary, without the approval of other interested parties, this is an implementation of sanctions by individuals ".

From the definition of eigenrechting as above, it can be interpreted that playing one's own rights is an act or method of vigilantism, taking rights without regard to the law, without government knowledge and without the use of governmental power tools. Besides, vigilanteism can also be interpreted as an act to punish a party without pass a process or procedure that is in accordance with the law.

Furthermore there is Teguh Prasetyo, who said that the purpose of criminal law by dividing it into 2 (two) parts, namely (1) the purpose of criminal law as sanction law. This goal is conceptual or philosophical in nature, aiming at providing the basis for criminal sanctions. Types of forms and criminal sanctions as well as parameters in resolving criminal violations. (2) The purpose in imposing criminal sanctions on people who violate criminal law. This goal is pragmatic with clear and concrete measures that are relevant to the problems that arise as a result of violations of criminal law and people who commit criminal law violations. This goal is an embodiment of the first goal. $^{2}$

Furthermore, in determining and realizing material truths must pay attention to the interests of the community and the interests of suspects, then in the "investigation process as an important effort in finding the true truth about the alleged criminal act and to find the guilty, is a task that must be really considered by the Police in his position as a state apparatus in handling the criminal investigation process that occurs in the community ". ${ }^{3}$

With the existence of legal objectives as a guarantor of certainty and orderly law as above, it can be understood that the act of execution, is not the right way, but is a violation of human rights. People may forget or even do not know, that not only do they have human rights, the perpetrators of crimes have rights that must be respected, namely the right to obtain legal protection before the court. Besides contradicting human rights, that the act of vigilantism (Eigenrechting), also cannot be justified, because the implementation of criminal sanctions is the monopoly of the authorities. Only the authorities have the power to impose sanctions, while individuals are not permitted to carry out sanctions to enforce the law. For example:

Based on the background that the authors describe above, the formulation of the problem How is the criminal law policy towards the perpetrators of criminal acts of persecution?

\footnotetext{
${ }^{2}$ Teguh Prasetyo, 2010, Hukum Pidana, Volume II, Jakarta, Rajawali Press, p. 7

${ }^{3}$ Martiman Prodjohamidjojo, 1984, Penyelidikan dan Penyidikan, Jakarta, Ghalia Indonesia, p. 17
} 


\section{Research Method}

The approach used in this study is a normative juridical or written legal approach (legislation/statute approach). A normative juridical approach is an approach that is based on the main legal material by studying the theories, concepts, the principles of law and the applicable laws and regulations relationship with this research. This approach is also known as the library approach, namely by studying books-books, legislation and other documents related to this research. ${ }^{4}$

This study uses descriptive research specifications analysis or the nature of the research object exposure. The data used for this research are secondary data. To get the data in this study, the data collection method is in the form of a literature study or document study. The data that has been obtained is then analyzed with qualitative analysis, namely data analysis by not using numbers, but data obtained through research.

\section{Results and Discussion}

\subsection{Understanding of Persecution}

In English, persecution is called persecution which means "hostility and ill-treatment, especially because of race or political or religious beliefs", or if translated freely as "hostility and persecution, especially because of race or political or religious beliefs". The Big Indonesian Dictionary, stated, that persecution is "persecution / execution / arbitrary hunting of a person or a number of citizens and hurt, distressed, or crushed". According to Damar Juniarto (Anti-Persecution Coalition Member from SAFEnet) Damar revealed that, Persecution was different from the main judiciary itself, in the true sense that the persecution was the act of hunting down a particular person or group. According to MasyhurEffendi, Taufani Sukmana Evandri, the definition of persecution is deliberate and cruel deprivation of basic rights and is related to negating group identity which constitutes a violation of international law. ${ }^{5}$ Although the definition of persecution and its moral implications, namely what is wrong, has not received much attention from many academics, Jaakko Kuosmanen has defined the definition of persecution by dismantling general assumptions based on historical cases. According to him, in order for a violation to be considered as a form of persecution, there are three conditions that are needed, conditions that must be determined: (1) asymmetrical and systemic threats; (2) severe and continuing hazards; and, (3) unfair discriminatory targets.

\footnotetext{
${ }^{4}$ Soerjono Soekanto and Sri Mamudji, 2010, Penelitian Hukum Normatif, PT. Rajagrafindo Persada: Jakarta, p. 14

${ }^{5}$ A. Masyhur Effendi, Taufani Sukmana Evandri, 2007, HAM dalam dimensi/dinamika yuridis, sosial, dan politik \& proses penyusunan/aplikasi HA-KHAM (hukum hak asasi manusia) dalam masyarakat, Ghalia Indonesia, p.155
} 
Persecution also goes far beyond religious, ethnic, and political groups, almost all of the striking differences in appearance or behavior can be used as a basis for persecution, such as homosexuality. The only red thread among the reasons above is the perception of different individuals / groups. Thus, persecution seems to be an expression of the tendency of a more general society in human social behavior, which seeks to impose or implement conformity. ${ }^{6}$

There are 2 (two) elements of the crime of persecution, which are categorized as follows:

- The crime was committed as part of a widespread and systematic attack aimed at a specific group of civilians;

- For the latter element, the perpetrators of this crime of persecution know if the act constitutes or with the intention of becoming part of a very widespread and systematic attack against certain civil groups. ${ }^{7}$

The act of persecution is a crime that is very troubling for some people, while the types of persecution include:

- Crimes Against Public Order

Crimes Against Public Order based on the Criminal Law Code, namely Article 167 Paragraph (1) Regarding Forcing to Enter a House Without Rights and Article 170 Paragraph (1) Regarding Beating.

- Crimes Against People's Independence

Crimes Against People's Independence based on the Criminal Law Code, namely Article 333 paragraph (1) concerning Judgment and Article 335 paragraph (1) point 1 and point 2 concerning Unpleasant Acts.

- Persecution

Persecution based on the Criminal Code namely Article 351 Concerning Persecution.

- Extortion and Threats

Extortion and threats based on the Criminal Code, Article 368 paragraph (1) Regarding Violence with Violence and Article 369 paragraph (1) Concerning Coercion by Threatening People.

\subsection{Criminal Law Policy against Persecutors of Criminal Acts}

The case of vigilantism (Eigenrechting) is one form of public reaction because of violations of norms that apply in the community. Community reaction, from a sociological perspective, can be divided into two aspects, namely positive and negative aspects. ${ }^{8}$ It must be recognized that the process / procedure of criminal law enforcement, in addition to providing legal certainty as well as efforts to protect the

\footnotetext{
6J Kuosmanen, 2014, What's so special about persecution? Ethical Theory and Moral Practice, Vol 17 No.1, p.129

${ }^{7}$ Lati MT Purta, 2018, Perbuatan Persekusi dari Sudut Pandang KUHP (Pasal 170 dan 335 KUHP), Jurnal Hukum Unsrat, Volume. 7 No. 2, p. 3

${ }^{8}$ Abdul Syahni, 1987, Sosiologi Kriminalitas, Bandung, Remaja Karya, p. 100
} 
human rights of alleged perpetrators of criminal acts. Based on the provisions of the Criminal Procedure Code, that every alleged criminal offense, before it can be said to be "guilty" is first required to go through the process / procedure stages and levels as above. This is in accordance with one of the principles of criminal procedure law, namely the presumption of innocence.

Provisions regarding the principle of presumption of innocence can be seen in Article 8 paragraph (1) of Law Number 48 Year 2009 concerning Judicial Power (hereinafter referred to as Law 48/2009), namely "Every person suspected, arrested, detained, be sued, or faced before a court must be deemed not guilty before a court ruling states his guilt and has obtained permanent legal force ".

In order to uphold the presumption of innocence, the provisions in the Criminal Procedure Code provide a set of rights that must be respected and protected by law enforcers. With the rights recognized by law, the position of the suspect / defendant becomes equal to law enforcement and has the right to demand the treatment outlined in the Criminal Procedure Code. From the description above, it can be understood, if there is a person or group suspected of being caught red-handed or committing a crime by the community, it should be reported to the authorities, namely the Police, then if the Police investigation and investigation finds elements of the crime, the process will naturally continues until the verdict stage in the Court.

As is known, that every criminal act must be accounted for by the perpetrators, not least in the case of criminal acts of persecution or vigilantism, the perpetrators of the persecution must also be held accountable for their actions. However, as stated by Mertokesumo, "Every violation of the law must basically be subject to penalty. But there are certain acts that are not subject to sanctions because of the reasons for criminal offenses ". ${ }^{9}$ Furthermore, Moeljatno, said that "criminal acts only point to the prohibited and threatened acts with a crime, so that every action can be held criminally accountable, depending on the question, whether in doing this act, he has a mistake". ${ }^{10}$

Although both are criminal offenses, but in the case of "exceptions to criminal offenses", the author must distinguish between persecution and playing into one's own hands. If in vigilantism, there are certain conditions that result, vigilance cannot be convicted, namely the existence of "reasons for criminal abolition". Take for example, if there is someone who is a victim of pickpocketing, and when the pickpocketing action is carried out, the victim knows and requests the return of goods, and then there is a breakdown between the perpetrator and the victim of pickpocketing, until in the end, the pickpocketer loses and suffers injuries.

Based on the above example, if only using criminal responsibility in the case of pickpocketing (theft) and ill-treatment, then it can be ascertained that both the

\footnotetext{
${ }^{9}$ Lidya Suryani Widayati, 2015, Tindakan Main Hakim Sendiri Dalam Kasus Begal, Jurnal Info Singkat Hukum Vol. Vii, No. 05/I/P3di/Maret 2015, Jakarta, Pusat Pengkajian, Pengolahan Data Dan Informasi (P3di) Secretariat General of the Indonesian Parliament, p. 2

${ }^{10}$ Moeljatno, 1993, Azas-Azas Hukum Pidana, Jakarta, Rineka Cipta, p. 165.
} 
perpetrators and victims of pickpocketing can be threatened with criminal, if the perpetrators of pickpocketing can be threatened with criminal provisions of Article 362 of the Criminal Code, namely take something, which is wholly or partly owned by another person, with the intention to be owned illegally, threatened with theft, with a maximum imprisonment of five years or a maximum fine of nine hundred rupiah ". Whereas victims of pickpocketing who carry out resistance can be threatened with articles of persecution, namely those contained in Article 351 of the Criminal Code:

- Persecution is punishable by imprisonment of up to two years and eight months or a maximum fine of four thousand five hundred rupiah;

- If the act results in serious injury, the guilty person is threatened with a maximum of five years in prison;

- If you result in death, you will be liable to a maximum of seven years imprisonment;

- With persecution equated deliberately damage health;

- Attempts to commit this crime were not convicted.

In accordance with the explanation above, for the perpetrators of pickpocketing / theft, it can be ascertained that his actions could be threatened with criminal. Based on the description above, although the act of pickpocketing victims who carry out the fight causes injury to the perpetrators of pickpocketing, so it can be categorized as an act of vigilante, but in terms of criminal liability, the victim of pickpocketing cannot be subject to criminal sanctions.

Whereas in the act of persecution, in terms of the ability to be responsible, of course the perpetrator is in a healthy condition both physically and spiritually, this can be seen from the efforts of the perpetrators of the persecution in searching for, finding and executing suspected criminal acts, so that the perpetrators of the persecution, can be threatened with criminal witnesses. the last element of criminal liability is that there is no justification or reason to eliminate criminal liability for the maker. In this case, the author is of the opinion that in the act of persecution, there are no elements that can be used as a reason for eradication or justification in criminal law.

The reason used by the writer is that in the act of persecution, there is an intention to want the purpose of the persecution, it can be seen from the stage of the action carried out, that is, it starts with finding and finding the target / victim of the execution, until finally carrying out the persecution of the victim, so it does not meet the elements the elements mentioned in the provisions of Article 44, Article 48, Article 49 and Article 51 of the Criminal Code.

Based on the description above, there is a clear difference, between criminal policy (for example) and acts of persecution, if in the act of vigilantism, still there are elements that can be used to use justification reasons in criminal acts, namely the provisions of Article 49 of the Criminal Code while in the act of persecution, the 
element of justification or forgiving reason is not fulfilled, so that in the act of execution there are no exceptions of criminal liability. regulated in the Criminal Code. ${ }^{11}$

\section{Closing}

\subsection{Conclusions}

As it is known, that not all criminal acts can be threatened with criminal offenses, because there are justification and forgiving reasons in criminal acts. For certain conditions, in the act of vigilante, especially in the case of self-defense / property / honor, justification reasons can be used, because it meets the elements mentioned in the provisions of the Criminal Code, especially Article 49 of the Criminal Code. Unlike the case with the act of persecution, according to the author, in the act of persecution there are no elements that can be used as justification and excuse for forgiveness in their actions, because when viewed from the process, the act of persecution, begins with finding, finding and executing suspected criminal offenses, of course it starts with intentions. Based on the description above,

\subsection{Suggestions}

- For law enforcement agencies, the need to socialize to the public at large, what and how criminal offenses are carried out and vigilantism can be processed by criminal law to be more sensitive to the law before taking an action that results in persecution;

- For the government, the need to make strict rules regarding the act of persecution in a regulation.

\section{References}

\section{Books}

[1] Abdul Syahni, 1987, Sosiologi Kriminalitas, Bandung, Remaja Karya

[2] A.Mashhur Effendi, Taufani Sukmana Evandri, 2007, HAM dalam dimensi/dinamika yuridis, sosial, dan politik \& proses penyusunan/aplikasi HA-KHAM (hukum hak asasi manusia) dalam masyarakat, Ghalia Indonesia

[3] Martiman Prodjohamidjojo, 1984, Penyelidikan dan Penyidikan, Jakarta, Ghalia Indonesia

[4] Moeljatno, 1993, Azas-Azas Hukum Pidana, Jakarta, Rineka Cipta

[5] Soerjono Soekanto and Sri Mamudji, 2010, Penelitian Hukum Normatif, PT. Rajagrafindo Persada: Jakarta

[6] Teguh Prasetyo, 2010, Hukum Pidana, Volume II, Jakarta, Rajawali Press

\footnotetext{
${ }^{11}$ Nur Pujayanti, Harry Soeskandi, 2019, Pelaku Persekusi dan Tindakan Main Hakim Sendiri, Jurnal Hukum, Mimbar Keadilan FH Untag Surabaya, Vol.14 No.28, p. 245
} 


\section{Regulations}

[1] The 1945 Constitution of the Republic of Indonesia

[2] Criminal Law Book

[3] Criminal Procedure Code

[4] Act No. 48 of 2009 on Judicial Power

\section{Journal}

[1] J Kuosmanen, 2014, What's so special about persecution? Ethical Theory and Moral Practice, Vol 17 No.1

[2] Lati M. T. Purta, 2018, Perbuatan Persekusi dari Sudut Pandang KUHP (Pasal 170 dan 335 KUHP), Jurnal Hukum Unsrat, Volume. 7 No. 2

[3] Lidya Suryani Widayati, 2015, Tindakan Main Hakim Sendiri Dalam Kasus Begal, Jurnal Info Singkat Hukum Vol. Vii, No. 05/I/P3di/Maret 2015, Jakarta, Center for Assessment, Data Processing and Information (P3di) DPR RI Secretariat General

[4] Nur Pujayanti, Harry Soeskandi, 2019, Pelaku Persekusi dan Tindakan Main Hakim Sendiri, Jurnal Hukum, Mimbar Keadilan FH Untag Surabaya, Vol.14 No.28 